\title{
Plasma enteroglucagon related to malabsorption in coeliac disease
}

\author{
A F KILANDER, G DOTEVAlL, G LindstedT, AND P-A LUNDBERG \\ From the Division of Gastroenterology, Department of Medicine II and Department of Clinical Chemistry, \\ University of Göteborg, Sahlgren's Hospital, Göteborg, Sweden
}

SUMMARY Plasma enteroglucagon was measured before and during three hours after a standard meal in 21 untreated adult patients with suspected coeliac disease who all had villous atrophy of the small intestinal mucosa and malabsorption, and in nine control subjects. In 11 of these patients the diagnosis of coeliac disease was confirmed and 10 were again investigated on a gluten free diet. The coeliac patients had higher basal $(37 \pm 9 \mathrm{pmol} / 1$, mean $\pm S E, p<0.05)$ and postprandial $(70 \pm 9 \mathrm{pmol} / \mathrm{l}, \mathrm{p}<0.005)$ mean plasma enteroglucagon concentrations than the control subjects (basal $14 \pm 4 \mathrm{pmol} / \mathrm{l}$, postprandial $25 \pm 5 \mathrm{pmol} / \mathrm{l}$ ). The 10 coeliac patients on gluten free diet for five to 20 months had a basal mean plasma enteroglucagon concentration not significantly lower than before treatment $(25 \pm 5 \mathrm{pmol} / \mathrm{l})$ but significantly lower postprandial enteroglucagon concentrations than before treatment $(40 \pm 7 \mathrm{pmol} / 1, \mathrm{p}<0 \cdot 025)$. Postprandial plasma enteroglucagon concentration after 90 minutes in untreated patients correlated positively to the faecal fat excretion $(r=0.58, p<0.02)$. It correlated negatively to the urinary five hour $D$-xylose excretion after an oral load of $165 \mathrm{mmol} D$-xylose $(r=-0.71, p<0.01)$. Thus, the postprandial plasma enteroglucagon concentrations in untreated coeliac disease were related to the degree of malabsorption and they normalised during treatment with a gluten free diet.

Biological activity similar to pancreatic glucagon has long been known to occur in the intestine. The presence of glucagon like immunoreactants also became evident after the development of glucagon radioimmunoassay. Purified preparations of 'enteroglucagon' from porcine intestine have been reported to be composed of the pancreatic glucagon amino acid sequence of 29 amino acids and a C-terminal octapeptide extension. ${ }^{1}$ Antibodies against the $\mathrm{N}$ terminal part of the glucagon molecule may cross react completely with enteroglucagon, but those against the C-terminal part may have negligible such cross reactivity. ${ }^{2}$ Enteroglucagon is located within the mucosal L-cells with a maximal concentration in the distal small intestine. ${ }^{3}$ It is released into the circulation after an oral glucose load or a mixed meal. ${ }^{4}$ Plasma enteroglucagon concentrations are increased greatly by intrajejunal glucose infusion and moderately by triglycerides whereas they are unchanged after infusion of hyperosmolal sodium chloride. ${ }^{5}$ The physiological role of enteroglucagon in man is so far unknown but a trophic effect on the Address for correspondence: A F Kilander, MD. Division of Gastroenterology. Department of Medicine II, University of Göteborg. Sahlgren s Hospital, S-413 45 Göteborg. Sweden.

Received for publication 5 August 1983 small intestinal mucosa has been suggested ${ }^{6}$ as well as an inhibition of the gastrin effect on the gastric acid secretion. ${ }^{7}$

High basal and postprandial plasma enteroglucagon concentrations have been found in patients with untreated coeliac disease. ${ }^{8}$ Coeliac patients treated with a gluten free diet have, however, normal enteroglucagon concentrations. It has therefore been suggested that determination of plasma enteroglucagon might be of value for detection and follow up of patients with coeliac disease. ${ }^{89}$ No studies of the same coeliac patients before and after gluten withdrawal, however, have to our knowledge been reported.

The purpose of this investigation was to determine fasting and postprandial plasma enteroglucagon concentrations in coeliac patients before and after treatment with a gluten free diet and to see if enteroglucagon assay may be useful in the follow up of the dietary treatment.

\section{Methods}

PATIENTS

Twenty one patients with villous atrophy and nine 
healthy volunteers were investigated. The study was approved by the ethical committee of the Medical Faculty of the University of Göteborg.

Twelve patients were studied before gluten withdrawal, nine women and three men aged between 24 and 78 years (mean age 49 years). Nine of these patients had a subtotal villous atrophy and three a partial villous atrophy of the small intestinal mucosa. The diagnosis of coeliac disease was confirmed by complete normalisation or obvious improvement of the mucosal morphology by light microscopy of a second biopsy specimen after treatment with a gluten free diet. Eleven of these patients were also studied after five to 20 months (mean 11 months) on a gluten free diet. One patient will be described separately; before the investigation for coeliac disease an intestinal resection was carried out because of a jejunal adenocarcinoma.

Nine patients, aged between 19 and 85 years (mean age 58 years), with probable coeliac disease and malabsorption, were also studied before any treatment with a gluten free diet. One patient refused any further investigations and one patient 85 years old, died three months after the initial investigation. In two cases a second biopsy showed no improvement of the intestinal morphology; this investigation had been made three and six months, respectively, after they were prescribed a gluten free diet. Five patients have been treated for a short time and a second biopsy has not yet been performed.

The renal function, judged by the concentration of serum creatinine, was normal in all patients.

Nine healthy volunteers took part in the study; there were five women and four men, aged between 18 and 46 years (mean age 35 years).

\section{D-XYLOSE ABSORPTION TEST}

D-xylose, $165 \mathrm{mmol}$ in $500 \mathrm{ml}$ water, was given to the patient in the morning after an overnight fast. Urine was collected for five hours and analysed for xylose. ${ }^{1011}$ An excretion of $33 \mathrm{mmol}$ or more is considered to be normal. The test was carried out once as part of the routine clinical evaluation before therapy.

\section{FAT ABSORPTION TEST}

The patient received a diet containing about $150 \mathrm{~g}$ fat daily (ordinary hospital diet plus $200 \mathrm{ml}$ milk cream) for five days. Faeces was collected during the final three days and the fatty acid content determined after alkaline hydrolysis. ${ }^{12}$ An excretion of less than $60 \mathrm{mmol}$ fatty acids per $72 \mathrm{~h}$ has been taken as normal. The test was carried out once as part of the routine clinical evaluation before therapy.

TEST MEAL

After an overnight fast the patients and the control subjects received a breakfast meal consisting of two boiled eggs, $60 \mathrm{~g}$ protein free bread, $15 \mathrm{~g}$ butter, $40 \mathrm{~g}$ orange marmalade, and $150 \mathrm{ml}$ orange juice with a total energy content of about $2500 \mathrm{~kJ}$. The amount of carbohydrate was estimated to be about $65 \mathrm{~g}$.

BLOOD SAMPLING

Blood was collected with 30 minute interval from 30 minutes before to three hours after the breakfast. Blood was drawn into heparinised, ice cooled glass tubes (Vacutainer ${ }^{\circledR}$, Becton Dickinson) containing 500 IU aprotinin (Trasylol ${ }^{\circledR}$, Bayer AG) per ml blood. The tubes were placed in a water bath with ice. Plasma was separated by centrifugation at $4^{\circ} \mathrm{C}$ within 15 minutes and stored at $-20^{\circ} \mathrm{C}$ until analysis.

\section{ASSAY OF PLASMA ENTEROGLUCAGON}

Plasma enteroglucagon concentrations were determined by radioimmunoassay, ${ }^{13}$ using reagents from Novo Research Institute (Bagsvaerd, Denmark). Antibody K 4023 was used for determination of the total plasma glucagon immunoreactivity and antibody $\mathrm{K} 5563$ for the pancreatic glucagon immunoreactivity. The antibody K 4023 has been shown to give linear dilution curves with crude pork gut glucagon like immunoreactants (GLI). ${ }^{14}$ When measured with $\mathrm{K} 5563$, the reaction with gut GLI has been found to be lower than $1 \% .^{15}$ The difference between the dose estimates with these antibodies was taken as a measure of the plasma enteroglucagon concentration. ${ }^{13}$ Porcine glucagon in phosphate buffer solution $(0.04 \mathrm{M}$

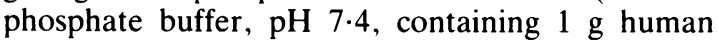
albumin (Behringwerke), $6 \mathrm{~g} \mathrm{NaCl}$, and $240 \mathrm{kIU}$ aprotinin/l) was used as standard and ${ }^{125}$ I-labelled pork glucagon as radioligand. Calibrators were assayed in triplicate and ethanol extracted plasma samples in duplicates. Plasma extracts were prepared by adding $1.8 \mathrm{ml} 96 \%$ ethanol to $0.5 \mathrm{ml}$ plasma diluted with $0.5 \mathrm{ml} 0.04 \mathrm{M}$ phosphate buffer ( $\mathrm{pH} 7.4)$ followed by centrifugation. The supernatants were decanted to small bottles and evaporated to dryness in a desiccator. The residues were dissolved in $0.5 \mathrm{ml}$ of the phosphate buffer. Calibrators and plasma samples were incubated at $4^{\circ} \mathrm{C}$ for $20-24$ hours before addition of $\left[{ }^{125} \mathrm{I}\right]$ glucagon solution. After another 20-24 hours 96\% ethanol was added to a final concentration of $85 \%$ to precipitate the antibody bound glucagon. The within assay imprecision of the glucagon assays was calculated from differences between the duplicate assays of single plasma sample extracts using values from pool samples and patient samples (Table 1). The within assay imprecision and bias (assay drift) for the enteroglucagon assays was calculated from 
Table 1 Within assay imprecision of glucagon analysis of extracted plasma samples calculated from the differences between duplicate assays of single plasma extracts.

'Pancreatic' glucagon was assayed with antibody K 5563 and 'total' glucagon was assayed with antibody K 4023

\begin{tabular}{|c|c|c|c|c|c|}
\hline $\begin{array}{l}\text { Antibody } \\
\text { preparation }\end{array}$ & $\begin{array}{l}\text { Concen- } \\
\text { tration } \\
\text { interval } \\
\text { (pmol/l) }\end{array}$ & $\begin{array}{l}\text { Plasma } \\
\text { samples } \\
\text { (no) }\end{array}$ & $\begin{array}{l}\text { Mean } \\
\text { concen- } \\
\text { tration } \\
(\text { pmol/l) }\end{array}$ & $\begin{array}{l}S D \\
(\text { pmolll })\end{array}$ & $\begin{array}{l}C V \\
(\%)\end{array}$ \\
\hline \multirow[t]{3}{*}{ K 5563} & $0-29$ & 321 & 22 & $1 \cdot 3$ & $5 \cdot 8$ \\
\hline & $30-57$ & 142 & 34 & $1 \cdot 3$ & 3.9 \\
\hline & 58 & 1 & 58 & 1.9 & $3 \cdot 3$ \\
\hline \multirow[t]{3}{*}{ K 4023} & $0-29$ & 8 & 19 & $2 \cdot 7$ & 14 \\
\hline & $30-86$ & 309 & 56 & $2 \cdot 9$ & $5 \cdot 2$ \\
\hline & $\geqslant 87$ & 141 & 130 & $4 \cdot 7$ & $3 \cdot 6$ \\
\hline
\end{tabular}

the differences in values obtained from two plasma pools analysed at the start and end of each assay run. The between assay imprecision of enteroglucagon was calculated from the differences between runs for three to five different plasma pool samples analysed at start of each assay run (Table 2).

\section{STATISTICAL ANALYSIS}

Student's $t$ test was used for statistical analysis of significance. The regression line was determined by the method of least squares. ${ }^{16}$

\section{Results}

PLASMA ENTEROGLUCAGON CONCENTRATIONS A significant increase of the mean plasma enteroglucagon concentration was found in the first samples 30 minutes after initiation of the meal in both control subjects and in patients (Fig. 1). After

Table 2 Within assay imprecision and total between assay imprecision for assay of plasma enteroglucagon. Within assay imprecision was calculated from differences between samples from two plasma pools analysed at start and at end of each assay run. The between assay imprecision was calculated from the differences between runs for 3-5 plasma pool samples analysed at start of each assay run

\begin{tabular}{|c|c|c|c|}
\hline \multirow{2}{*}{$\begin{array}{l}\text { Mean concen- } \\
\text { tration of } \\
\text { plasma pool } \\
\text { sample } \\
\text { (pmolll) }\end{array}$} & \multirow{2}{*}{$\begin{array}{l}\text { Assay } \\
\text { runs } \\
\text { (no) }\end{array}$} & \multicolumn{2}{|c|}{ Coefficient of variation $1 \%$} \\
\hline & & $\begin{array}{l}\text { Within } \\
\text { assay }\end{array}$ & $\begin{array}{l}\text { Between } \\
\text { assay }\end{array}$ \\
\hline 19 & 16 & 14 & 19 \\
\hline 28 & 12 & - & 13 \\
\hline 40 & 13 & 3.4 & $8 \cdot 6$ \\
\hline 46 & 12 & - & $9 \cdot 7$ \\
\hline 50 & 16 & - & 17 \\
\hline
\end{tabular}

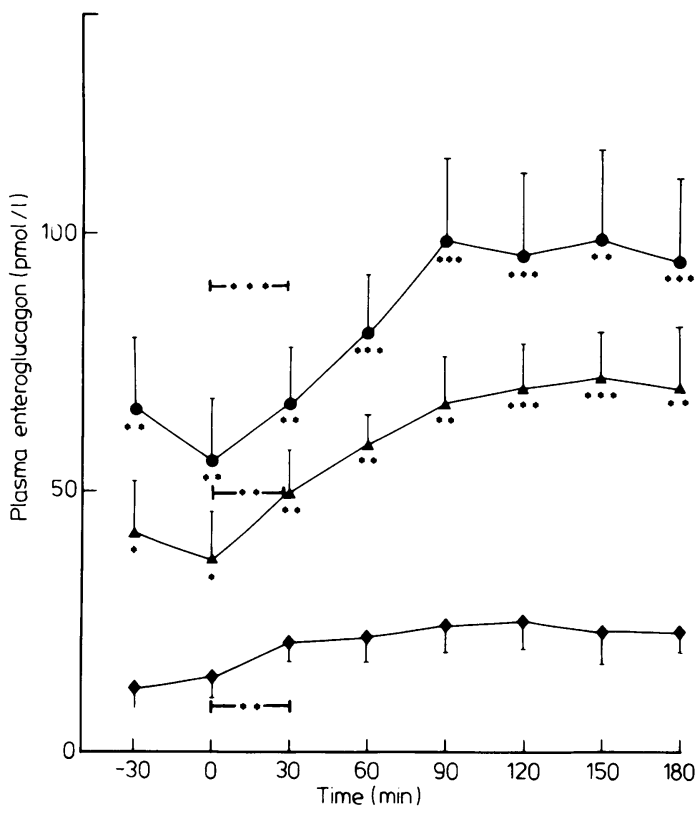

Fig. 1 Plasma enteroglucagon concentration (mean $\pm S E$ ) before and after a test meal in control subjects $(\diamond, n=9)$, patients with probable coeliac disease $(\mathbf{O}, n=9)$, and patients with untreated coeliac disease $(\Delta, n=11)$.

Patients and control subjects had meal at 0 minutes and had usually finished within 15 minutes. Stars indicate the level of significance in relation to control subjects and stars within solid lines that between 0 samples and 30 minute samples for each group. Levels of significance: ${ }^{*} p<0.05,{ }^{* *} p<0.01$, ${ }^{* * *} p<0 \cdot 001$.

90 minutes no further concentration increase was observed in the patients or in controls.

The mean basal plasma enteroglucagon concentration (mean $\pm \mathrm{SE}$ ) was at all sampling times significantly higher in untreated coeliac disease $(37 \pm 9 \mathrm{pmol} / \mathrm{l})$ and in probable coeliac disease $(56 \pm 12 \mathrm{pmol} / \mathrm{l})$ than in control subjects $(14 \pm 4$ $\mathrm{pmol} / \mathrm{l})$. During the period $90-180$ minutes the patients with coeliac disease and those with probable coeliac disease had significantly higher plasma enteroglucagon concentrations than control subjects (mean value for the four samples being $70 \pm 9 \mathrm{pmol} / \mathrm{l}$ and $100 \pm 16 \mathrm{pmol} / \mathrm{l}$, respectively, compared with $25 \pm 5 \mathrm{pmol} / \mathrm{l}, \mathrm{p}<0 \cdot 005)$.

The treated patients $(n=10)$ had significantly lower concentrations $(40 \pm 7 \mathrm{pmol} / \mathrm{l})$ during the period 90-180 minutes $(p<0.025)$ than before treatment, which was not significantly higher than in control subjects (Fig. 2). The basal mean plasma enteroglucagon concentration $(25 \pm 5 \mathrm{pmol} / \mathrm{l})$ was not significantly lower than the pretreatment 


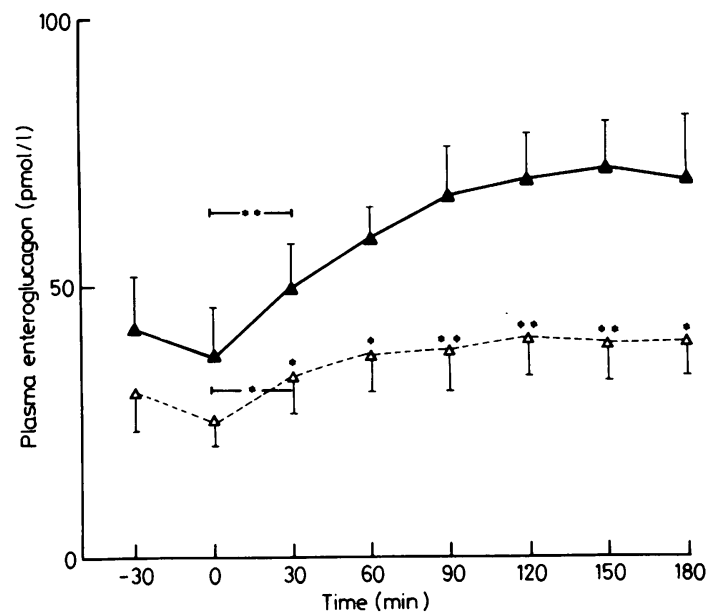

Fig. 2 Plasma enteroglucagon concentration (mean $\pm S E$ ) before and after a test meal in patients with coeliac disease before $(\Delta, n=11)$ and after $(\triangle, n=10)$ treatment with a gluten free diet. Time for the meal as in Fig. 1. Symbols for degree of statistical significance of differences as in Fig. 1.

concentration. The patient with jejunal resection because of adenocarcinoma had the highest postprandial plasma enteroglucagon concentration, highest value being $210 \mathrm{pmol} / \mathrm{l}$ before treatment and $70 \mathrm{pmol} / \mathrm{l}$ after treatment.

An overlap of the postprandial concentrations in patients with coeliac disease and in control subjects was observed (Fig. 3).

\section{RELATION BETWEEN PLASMA ENTEROGLUCAGON} AND MALABSORPTION

Plasma enteroglucagon concentration either at 90 , 120 , or 150 minutes was found to be correlated to the faecal fat excretion (Fig. 4). A negative correlation to the D-xylose excretion during an absorption test was found at $90,120,150$, as well as at 180 minutes (Fig. 5). Table 3 shows the frequency of abnormal malabsorption tests and postprandial plasma enteroglucagon concentrations above the range of the control subjects.

\section{Discussion}

This study confirms results from a previous study ${ }^{8}$ that postprandial plasma enteroglucagon concentrations are higher in untreated coeliac disease than in control subjects. It also shows that dietary treatment of these patients is followed by lower plasma enteroglucagon concentrations. Furthermore, we found that the postprandial plasma enteroglucagon concentrations were related to the

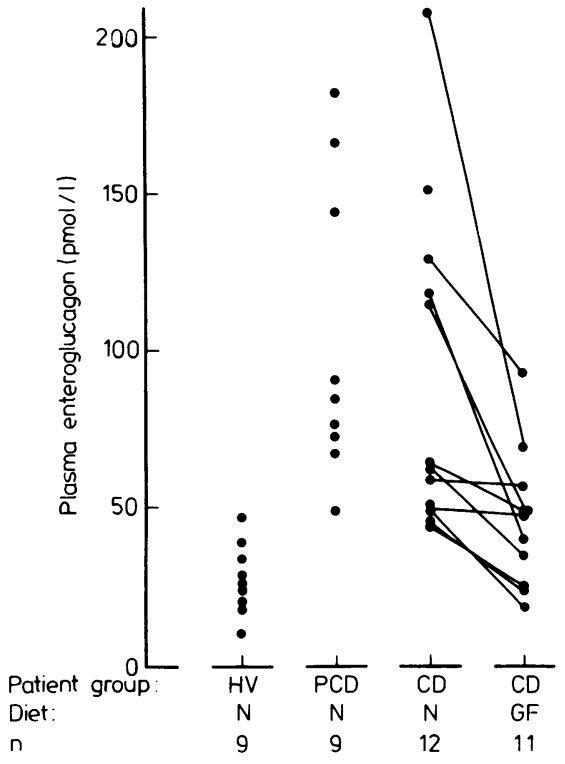

Fig. 3 Maximal postprandial plasma enteroglucagon concentrations in healthy volunteers $(H V)$, in patients with probable coeliac disease ( $P C D)$, and in patients with coeliac disease $(C D)$ on normal diet $(N)$ and after treatment with a gluten free diet $(G F)$.

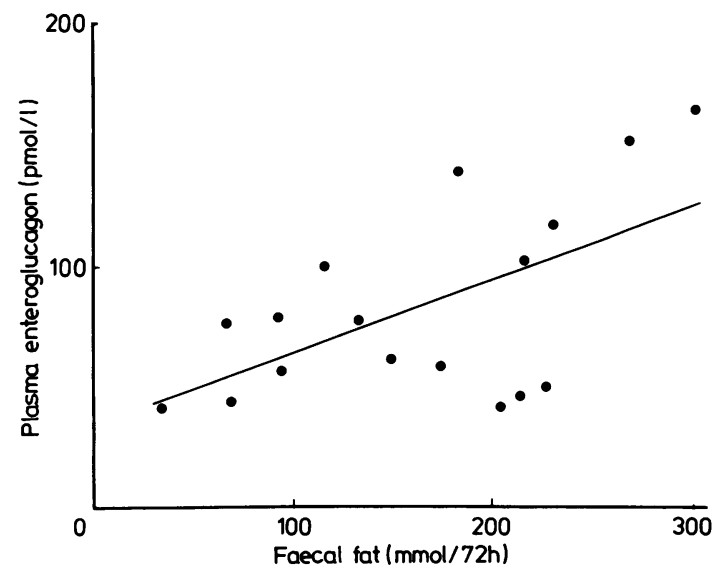

Fig. 4 Correlation between plasma enteroglucagon concentrations at 90 minutes after the test meal and the faecal fat excretion (expressed as fatty acids) in patients with coeliac disease and probable coeliac disease $(n=17, r=0.58$, $p<0.02$ ) 


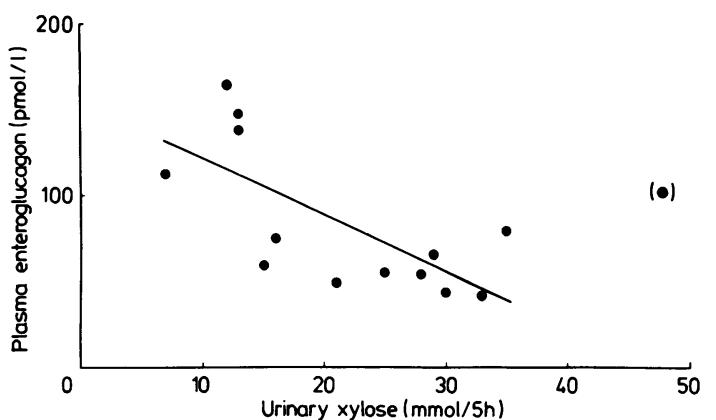

Fig. 5 Correlation between plasma enteroglucagon concentrations at 90 minutes after test meal and urinary $D$-xylose excretion after oral loading test in untreated patients with coeliac disease and probable coeliac disease $(n=13, r=-0.71, p<0.01)$. One value, a $D-x y l o s e$ excretion of $48 \mathrm{mmol} / 5 \mathrm{~h}$, was regarded as an outlier and has been excluded from the calculations.

degree of malabsorption in untreated coeliac disease. This finding may partly explain the differences found in comparison between our values and those reported by others (Table 4) as well as the large inter-individual differences in our study as well as in reference 8 (judged by the reported variations). Methodological differences conceivably are present as well.

That the release of enteroglucagon is related to the faecal fat excretion and negatively to the urinary D-xylose excretion in coeliac disease agrees with the findings reported by Carson et al, ${ }^{9}$ who studied children during gluten challenge. They reported negative correlations between the total $\mathrm{N}$-terminal glucagon like immunoreactivity (enteroglucagon plus pancreatic glucagon) and the blood D-xylose concentration 60 minutes after oral D-xylose ingestion as well as to fasting cholesterol.
Table 3 Frequency of positive test results in untreated coeliac disease. Postprandial plasma enteroglucagon concentrations above the range in control subjects $(>48$ pmol/l) are regarded as positive results for coeliac disease

\begin{tabular}{lll}
\hline Test & $\begin{array}{l}\text { Patients } \\
\text { (no) }\end{array}$ & $\begin{array}{l}\text { Positive test } \\
\text { results (no) } \\
\text { (frequency, \%) }\end{array}$ \\
\hline Faecal fat excretion & 17 & $16(94)$ \\
D-xylose excretion & 14 & $11(78)$ \\
Postprandial entcroglucagon & 21 & $19(90)$ \\
\hline
\end{tabular}

The small increase of the plasma enteroglucagon concentrations in the control subjects after the meal in our study accords with the results reported by Besterman et al. ${ }^{8}$ A more pronounced increase has been observed after intrajejunal infusion of glucose or triglycerides. ${ }^{5}$ In several gastrointestinal disorders, such as chronic pancreatitis, ${ }^{17}$ Crohn's disease, ${ }^{18}$ dumping syndrome, ${ }^{19}$ after small intestinal resections ${ }^{20}$ and jejunoileal bypass ${ }^{21}$ the postprandial plasma enteroglucagon concentrations are significantly higher than in control subjects. After jejunoileal bypass operations Holst et al ${ }^{2}$ found higher plasma enteroglucagon concentrations in the patients with a short remaining jejunal part and a longer ileal part than in those with the reversed relation with a long jejunal segment and a short ileal part. These findings support the hypothesis $^{21}$ that enteroglucagon is released when unabsorbed intestinal content reaches the distal part of the small intestine and the colon, where the tissue concentration of enteroglucagon is highest. Enteroglucagon is located within the L-cells, which reach the intestinal lumen, terminating in microvilli. ${ }^{3}$ In coeliac disease the proximal part of the small intestine is more severely affected than the distal part. $^{2223}$ Thus, that part of the intestine containing

Table 4 Reported values (mean $\pm S E$ ) for plasma enteroglucagon concentration in coeliac disease. Data from ref 9 were recalculated to SI units assuming a molecular mass of 3485 dalton

\begin{tabular}{|c|c|c|c|c|}
\hline Type of sample & Clinical group & $\begin{array}{l}\text { Enteroglucagon } \\
(\text { pmolll) } \\
\text { Besterman et al }{ }^{\times}\end{array}$ & Present study & $\begin{array}{l}\text { Total GLI* } \\
\text { (pmol/l) } \\
\text { Carson et } \mathrm{al}^{9}\end{array}$ \\
\hline \multirow[t]{4}{*}{ Fasting } & Controls & $28 \pm 7$ & $14 \pm 4$ & - \\
\hline & Coeliac disease & $97 \pm 31$ & $37 \pm 9$ & - \\
\hline & Treated coeliac disease ${ }^{\dagger}$ & $34 \pm 7$ & $25 \pm 5$ & $32 \pm 12$ \\
\hline & After gluten challenge & - & - & $53 \pm 14$ \\
\hline \multirow[t]{4}{*}{ Postprandial $\ddagger$} & Controls & $45 \pm 11$ & $25 \pm 5$ & - \\
\hline & Coeliac disease & $263 \pm 62$ & $70 \pm 9$ & - \\
\hline & Treated coeliac disease ${ }^{t}$ & $59 \pm 8$ & $40 \pm 7$ & $28 \pm 9$ \\
\hline & After gluten challenge & - & - & $60 \pm 15$ \\
\hline
\end{tabular}

* Total glucagon like immunoreactivity. + Gluten free diet. $\ddagger$ After a mixed meal in ref 8 and in present study: after an oral glucose load in ref 9 . 
the enteroglucagon cells is preserved and it is exposed to an increased amount of unabsorbed luminal content after a meal. Our findings of a correlation between the postprandial plasma enteroglucagon concentrations and the degree of malabsorption support the hypothesis mentioned above and indicate that the amount of unabsorbed intestinal content is important for the release of enteroglucagon.

The number of patients and control subjects in our study is too low to allow a full evaluation of the possibility that determination of plasma enteroglucagon concentrations could be used as a test for detection of coeliac disease in adults. Postprandial values seem to separate the groups more clearly than fasting values. The fact that the postprandial plasma enteroglucagon concentrations were lower after treatment with a gluten free diet implies that it is possible to follow the improvement of the malabsorption and the adherence to the diet with repeated determinations. The plasma enteroglucagon assay still presents some problems as regards assay performance and interpretation of values: (a) the methodological variations are high even if the CVs of both the 'glucagon' and 'total glucagon' assays are satisfactory by present standards for polypeptide assays; (b) extraction efficiency and degree of heterogeneity of plasma 'enteroglucagon' in different clinical states are still less well defined. The present results, our results for children, ${ }^{24}$ as well as the results reported by others do indicate a clinical value of the enteroglucagon assay in coeliac patients which will encourage work in development of more satisfactory assays.

Part of this study was presented at the Annual Meeting of the Swedish Medical Society in Stockholm, 1982. The expert technical assistance of Mrs Gunnel Lundquister is gratefully acknowledged. This study was supported by grants from the Göteborg Medical Society, the Medical Faculty of the University of Göteborg, and the Swedish National Association for Patients with Gastrointestinal Diseases.

\section{References}

1 Bataille D, Tatemoto $\mathrm{K}$, Gespach C, Jörnvall $\mathrm{H}$, Rosselin G, Mutt V. Isolation of glucagon-37 (bioactive enteroglucagon/oxyntomodulin) from porcine jejunoileum. Characterization of the peptide. FEBS Lett 1982; 146: 79-86.

2 Sundy F, Moody AJ. Gut glucagon-like immunoreactants (GUT GLIs): isolation, structure, and possible role. In: Glass GBJ, ed. Gastrointestinal hormones. New York: Raven Press, 198(): 3(1)7-13.

3 Grimelius L, Polak JM, Solcia E, Pearse AGE. The enteroglucagon cell. In: Bloom SR, ed. (jut hormones. Edinburgh, London, New York: Churchill Livingstone, 1978: 365-8.

4 Moody AJ, Sundby F. Radioimmunoassay of gut glucagon-like immunoreactants. In: Glass GBJ, ed. Gastrointestinal hormones. New York: Raven Press, 1980: 831-9.

5 Holst JJ, Christiansen J, Kühl C. The enteroglucagon response to intrajejunal infusion of glucose, triglycerides, and sodium chloride, and its relation to jejunal inhibition of gastric acid secretion in man. Scand J Gastroenterol 1976; 11: 297-3(1)4.

6 Bloom SR, Polak JM. Trophic influences in the gut. In: Bloom SR, Polak JM, Lindenlaub E, eds. Systemic role of regulatory peptides. Stuttgart, New York: F K Schattauer Verlag, 1982: 211-27.

7 Dubrasquet M, Bataille D, Gespach C. Oxyntomodulin (glucagon-37 or bioactive enteroglucagon): a potent inhibitor of pentagastrin-stimulated acid secretion in rats. Biosci Rep 1982; 2: 391-5.

8 Besterman HS, Bloom SR, Sarson DL et al. Guthormone profile in coeliac disease. Lancet 1978; 1: 785-8.

9 Carson DJ, Glasgow JFT, Buchanan KD. Sloan JM. Changes in $\mathrm{N}$-terminal glucagon-like immunoreactivity and insulin during short-term gluten challenge in childhood coeliac disease. Gut 1981; 22: 554-7.

10 Roe JH, Rice EW. A photometric method for the determination of free pentoses in animal tissues. $J$ Biol Chem 1948; 173: 507-12.

11 Kerstell J. A simplified method for the determination of xylose in urine. Scand J Clin Lab Invest 1961: 13: 637-41.

12 van de Kamer JH, ten Bokkel Huinink H, Weyers HA. Rapid method for the determination of fat in feces. $J$ Biol Chem 1949; 177: 347-55.

13 Heding LG. Radioimmunological determination of pancreatic and gut glucagon in plasma. Diabetologia 1971; 7: 10-19.

14 Heding LG, Frandsen EK, Jacobsen H. Structurefunction relationship: immunologic. Metabolism 1976: 25: 1327-9.

15 Instruction sheet. Anti-porcine-glucagon rabbit serum $K$ 5563. Novo Research Institute, Bagsvaerd, Denmark, 1979.

16 Bailey NTJ. Statistical methods in biology. 2nd ed. London: Hodder and Stoughton, 1981.

17 Besterman HS, Adrian TE, Bloom SR et al. Pancreatic and gastrointestinal hormones in chronic pancreatitis. Digestion 1982; 24: 195-208.

18 Besterman HS. Bloom SR. Christofides ND. Mallison CN. Pera A. Modgliani R. Gut hormone profile in inflammatory bowel disease. [Abstract] Gut 1978; 19: A 988-9.

19 Bloom SR. Royston CMS. Thomson JPS. Enteroglucagon release in the dumping syndrome. Lancet 1972: 2: 789-91.

20 Besterman HS, Adrian TE. Mallinson CN et al. Gut hormone release after intestinal resection. Gut 1982: 23: 854-61. 
21 Holst JJ, Sörensen TIA. Andersen AN et al. Plasma enteroglucagon after jejunoileal bypass with $3: 1$ or $1: 3$ jejunoileal ratio. Scand J Gastroenterol 1979; 14: $205-7$.

22 MacDonald WC. Brandborg LL, Flick AL. Trier JS. Rubin CE. Studies on celiac sprue. IV. The response of the whole length of the small bowel to a gluten-free diet. Gastroenterology 1964; 47: 573-89.

23 Stewart JS. Adult coeliac disease. Postgrad Med J 1968; 44: $632-40$.

24 Kilander AF, Stenhammar L, Lindstedt G, Lundberg P-A. Determination of enteroglucagon in plasma for detection of celiac disease in children. Clin Chem 1984; 30: $77-80$. 